\title{
Novel Investigation on Ammonium Thiosulphate (ATS) as an Inhibitor of Soil Urease and Nitrification
}

\author{
Alja Margon1, Giuseppe Parente1, Michele Piantanida² ${ }^{2}$ Pierpaolo Cantone ${ }^{1}$, Liviana Leita ${ }^{*}$ \\ ${ }^{1}$ Consiglio per la ricerca in agricoltura e l'analisi dell' economia agraria (Council for Agricultural Research and \\ Economics), Gorizia, Italy \\ ${ }^{2}$ ESSECO s.r.I., San Martino di Trecate, Novara, Italy \\ Email: *liviana.leita@entecra.it
}

Received 2 November 2015; accepted 23 December 2015; published 28 December 2015

Copyright @ 2015 by authors and Scientific Research Publishing Inc.

This work is licensed under the Creative Commons Attribution International License (CC BY). http://creativecommons.org/licenses/by/4.0/

\section{Abstract}

Among the numerous products so far promoted as effective urease and/or nitrification inhibitors, it is possible to detect a renewed interest in environmentally friendly tools, such as ammonium thiosulphate (ATS, $\left(\mathrm{NH}_{4}\right)_{2} \mathrm{~S}_{2} \mathrm{O}_{3}$ ) which is currently used as fertilizer for $\mathrm{N}$ and $\mathrm{S}$ nutrition. Among contradictory results accounted in the current literature, there is reported that ammonium thiosulphate (ATS) exerts inhibitory activity at large but unlikely agronomic rates of $2500-5000$ $\mathrm{mg} \cdot \mathrm{kg}^{-1}$ soil. We carried out a novel experiment aimed to: a) verify the inhibitory action of ATS, even when applied in soil at low rates $\left(25\right.$ and $100 \mathrm{mg} \cdot \mathrm{kg}^{-1}$ soil as S-ATS), towards urease activity and nitrification in urea treated and not treated soils; $b$ ) investigate on the influence of ATS on the soil microbial biomass as it is generally assumed that soil microorganisms are the main agents of urea hydrolysis. For these purposes we selected an arable sandy soil and a grassland sandy-loam soil which are treated with urea or/and ATS. Results obtained from this novel investigation showed that a) ATS significantly decreased urease activity in both soil types and that the exerted inhibitory effect was moderate and short-term; b) ATS retarded the hydrolysis of urea and lowered nitrate production in the urea treated soils; c) the available fraction of iron and manganese in the used soils might be involved in the mechanism of inhibition; d) ATS did not affect the size of soil microbial biomass pool; e) the efficiency of ATS as urease and nitrification inhibitor was more evident in the sandy soil. Because of its properties, ATS may be applicable on many crops without being harmful on the soil microbial pool.

\section{Keywords}

Ammonium Thiosulphate, Inhibitor, Urease, Nitrification, Soils

\footnotetext{
${ }^{*}$ Corresponding author.
}

How to cite this paper: Margon, A., Parente, G., Piantanida, M., Cantone, P. and Leita, L. (2015) Novel Investigation on Ammonium Thiosulphate (ATS) as an Inhibitor of Soil Urease and Nitrification. Agricultural Sciences, 6, $1502-1512$. 


\section{Introduction}

To cope with an increasing global population, rapid depletion of natural resources, increasing environmental pressures and climate changes, there is a worldwide necessity to radically change the approach to consumption and production and to concomitantly optimize the efficiency of use of natural and anthropogenic resources [1]. Modern agriculture nowadays feeds 6 billion people, and the global cereal production has doubled in the past 40 years, mainly because of the increased yields resulting from greater fertilizer input, irrigation and pesticides, new crops varieties, and other technologies implemented during the "Green Revolution” [2].

There is a general consensus that, under the current trends, the global population could increase by $40 \%$ within 2050 and the global grain demand would roughly double [3]. Doubling and sustaining grain production without compromising the three pillars of sustainability (i.e. environmental integrity, public health and economic benefits) is currently a major challenge and it will be even a greater challenge in the future [4] [5]. Agricultural practices influence not only grain yields and food production in general, but also the state of the global environment. Intensive agriculture depends, to a great degree, on the use of synthetic fertilizers and industrially produced $\mathrm{N}$ is the main source of $\mathrm{N}$ input in the crop production system worldwide.

However, nitrogen is not only an essential plant nutrient that guarantees high-yield production, it is also a pollutant. Large external inputs of $\mathrm{N}$ fertilizer coupled with decreasing $\mathrm{N}$ use efficiency contribute to severe environmental pollution, including the degradation of downstream water quality, development of photochemical smog, and rise of global concentrations of gaseous $\mathrm{N}$-oxides, which are known to be powerful greenhouse gases [6] [7].

It is well known that only $30 \%$ - $50 \%$ of applied $\mathrm{N}$ is taken up by crops. The unaccounted percentage represents $\mathrm{N}$ losses due to volatilization or leaching processes [8] [9]. $\mathrm{N}$ losses can therefore be deleterious for offsite ecosystems, especially considering that in the past half century the global use of $\mathrm{N}$ fertilizer increased about tenfold and is expected to further increase by 2050 unless there is a substantial increase in fertilizer efficiency.

Most of the $\mathrm{N}$ fertilizers applied to soils for agriculture production are in the form of $\mathrm{N}$ - $\mathrm{NH}_{4}^{+}$(ammoniumsulphate, ammonium-nitrate) or $\mathrm{NH}_{4}^{+}$compounds. Urea in particular is the most widely used $\mathrm{N}$ source in agriculture worldwide [10] [11], but its efficiency is markedly reduced by nitrous/ammonia and nitrate losses that are significantly affected by weather conditions and vary between soil types [12]-[16].

In most arable soils urea is rapidly converted to ammonia by urease (a metalloenzyme able to catalyse the hydrolysis of urea to ammonia and carbamate). This leads to volatilization of ammonia and emissions of nitrous oxides. In addition, ammonium in soil is rapidly oxidized via chemical and biological pathways, the latter leading first to the production of nitrite $\left(\mathrm{NO}_{2}^{-}\right)$and then to nitrate $\left(\mathrm{NO}_{3}^{-}\right)$. Nitrate is soluble, negatively charged, mobile in soil and therefore subjected to leaching. For these reasons, controlling the processes of nitrification and/or urease hydrolysis is a potential tool to restrict $\mathrm{N}$ leaching and ammonia/nitrous volatilization from soils.

A concomitant achievement of high agricultural yields, food security and environmental sustainability is possible, but this would require considerable changes in nutrient management [17]; firstly, by avoiding the overuse of $\mathrm{N}$ fertilizers, and secondly by achieving a higher efficiency of $\mathrm{N}$ fertilization which would be the key to optimizing the trade-off among yield, profit, and environmental protection.

With increasing public concern regarding health issues, environmental protection and natural resource sustainability, there is a shift toward the development of environmentally friendly agricultural practices that aim to maximize $\mathrm{N}$ fertilizer efficiency. Accordingly, the goal of the precision fertilization is to get the right rate of fertilizer to match the actual $\mathrm{N}$ needs of crops and supply at the right time of the growing stage, thereby minimizing nutrient losses and raising profitability. Improving the efficiency of urea-based fertilizers through new technologies and management strategies would therefore be of tangible interest. One of the most promising approaches is fertilization with urea in combination with urease/nitrification inhibitors. Commercial products address either on urease activity or nitrification. However, the strong and long-lasting inhibitory effect exhibited by most of them might be detrimental for crops with short growing periods (especially maize $\sim 130 \mathrm{dd}$ ), which require high $\mathrm{N}$ uptake over a very short period of time.

Among the numerous products so far promoted as urease or nitrification inhibitors, there is nowadays a renewed interest concerning the use of environmentally friendly tools, such as ammonium thiosulphate $\left(\left(\mathrm{NH}_{4}\right)_{2} \mathrm{~S}_{2} \mathrm{O}_{3}\right)$ (ATS) which is currently used as fertilizer for $\mathrm{N}$ and $\mathrm{S}$ nutrition. The ability of the fertilizer ammonium thiosulphate in conjunction with urea to retard the hydrolysis of urea by soil urease and nitrification was reported by several experts [18]-[24]. However, in their reports the authors evidenced inhibitory effects only when ATS was 
used at rates of $2500 \mathrm{mg} \cdot \mathrm{kg}^{-1}$ soil. By contrast, McCarty et al. [25] found that ATS showed little, if any, potential value for retarding hydrolysis of urea fertilizer in soil, even at rates higher than $5000 \mathrm{mg} \cdot \mathrm{kg}^{-1}$ soil. To contribute to the knowledge we carried out a novel experiment aimed to verify the inhibitory effect of ATS applied to soil at lower rates (25 and $100 \mathrm{mg} \cdot \mathrm{kg}^{-1}$ soil as S-ATS), towards urease and nitrification in original and in urea treated soils, and hypothesize the mechanisms involved. To these purposes we selected an arable sandy soil and a grassland sandy-loam soil which were amended with urea or/and ATS.

\section{Materials and Methods}

\subsection{Soil}

Composite samples of two soils from NE Italy were collected at 2 - $10 \mathrm{~cm}$ depth. We sampled a grassland sandy-loam soil (A) (Gorizia 45 56'6,7"N, 1337'95"E, a grassland Mollic Hapludalf soil, USDA 1999) and an arable sandy soil (B) (San Martino 46 ${ }^{\circ} 1^{\prime} 0^{\prime \prime N}, 12^{\circ} 52^{\prime} 0^{\prime \prime E}$, a Fluventic Eutrudept arable soil, USDA 1999). Each fresh soil sample was sieved to $2 \mathrm{~mm}$ to remove rocks and root materials, thoroughly hand-mixed, and divided into two subsamples. One subsample was stored at $4^{\circ} \mathrm{C}$ until incubation began. The other subsample was airdried to measure soil parameters, according to SSSA standards [26].

Selected chemical characteristics of the used soils are reported in Table 1.

\subsection{Soil Treatments}

Soil samples were adjusted to $35 \%$ of their respective water holding capacity (WHC) and pre-conditioned in airtight plastic containers at $20^{\circ} \mathrm{C}$ for 7 days to allow microbial activity to regain its equilibria after the initial disturbance [27].

Soil samples were then treated with ATS, and/or urea solutions in order to add $25 \mathrm{ppm}$ of S (corresponding to $32.5 \mathrm{~kg} \mathrm{~S}-\mathrm{ATS} \mathrm{ha}^{-1}$ ), $100 \mathrm{ppm}$ of S (corresponding to $130 \mathrm{~kg} \mathrm{~S}$-ATS ha $^{-1}$ ) and $150 \mathrm{~kg} \mathrm{~N} \mathrm{ha}^{-1}$ to soil as urea or urea plus ATS (Table 2). The ATS and urea working solutions were prepared by diluting urea and the commercial product Secofit ${ }^{\circledR}$ TS (ATS) in water. The concentration of the applied solution was calculated to bring the soil to 40\% WHC after addition. The control (T0) received only distilled water. The treated soils were then placed in airtight plastic boxes. Two jars containing respectively distilled water and $1 \mathrm{M} \mathrm{NaOH}$ were put into each box to prevent changes in water content and to trap the evolved $\mathrm{CO}_{2}$. The boxes were then placed in an incubator at $20^{\circ} \mathrm{C}$ for 15 days. The soil moisture level was controlled twice a week and adjusted when necessary. To avoid the onset of anaerobic conditions, the boxes were opened once a day and the soil samples thoroughly mixed. The applied doses were calculated on the basis of the soil density $\left(1.3 \mathrm{t} \cdot \mathrm{m}^{-3}\right)$.

Table 1. Selected parameters for soil characterization.

\begin{tabular}{ccccccccccc}
\hline Soil & Sand & Silt & Clay & $\mathbf{p H}$ & $\mathbf{C S C}$ & $\mathbf{C}_{\mathbf{O R G}}$ & $\mathbf{N}_{\text {TOT }}$ & $\mathbf{C}_{\text {MIC }}$ & Available Fe & Available Mn \\
& $(\%)$ & $(\%)$ & $(\%)$ & & $\mathrm{Cmol}^{+} \mathrm{kg}^{-1}$ & $\mathrm{~g} \cdot \mathrm{kg}^{-1}$ & $\mathrm{~g} \cdot \mathrm{kg}^{-1}$ & $\mu \mathrm{g}^{-1}$ & $\mathrm{mg} \cdot \mathrm{kg}^{-1}$ & $\mathrm{mg} \cdot \mathrm{kg}^{-1}$ \\
\hline Sandy loam (A) & 37 & 48 & 15 & 7.8 & 8.2 & $25.4 \pm 1.6$ & $2.8 \pm 0.26$ & $720 \pm 54$ & $21 \pm 1.8$ & $23 \pm 1.7$ \\
Sandy (B) & 68 & 28 & 3 & 8.3 & 3.5 & $6.5 \pm 0.4$ & $0.9 \pm 0.08$ & $155 \pm 13$ & $8 \pm 0.7$ & $12 \pm 1.0$ \\
\hline
\end{tabular}

Table 2. Scheme of the soil treatments.

\section{Soil treatment}

\begin{tabular}{|c|c|}
\hline & Soil treatment \\
\hline T0 & Control soil \\
\hline $\mathrm{T} 1$ & Urea 150 kg $\mathrm{N} \mathrm{ha}{ }^{-1}$ \\
\hline $\mathrm{T} 2$ & ATS as 32.5 kg S-ATS ha ${ }^{-1}$ (i.e. 25 ppm S-ATS) \\
\hline T3 & ATS as $130 \mathrm{~kg} \mathrm{S-ATS} \mathrm{ha}{ }^{-1}$ (i.e. 100 ppm S-ATS) \\
\hline $\mathrm{T} 4$ & $150 \mathrm{~kg} \mathrm{~N} \mathrm{ha}^{-1}$ as ATS (32.5 kg S ha $\left.{ }^{-1}\right)+$ urea $\left(134 \mathrm{~kg} \mathrm{~N} \mathrm{ha}^{-1}\right)$ \\
\hline $\mathrm{T} 5$ & $150 \mathrm{~kg} \mathrm{~N} \mathrm{ha}^{-1}$ as ATS (130 kg S-ATS ha ${ }^{-1}+$ urea $\left(85 \mathrm{~kg} \mathrm{~N} \mathrm{ha}^{-1}\right)$ \\
\hline
\end{tabular}


The scheme of the soil treatments is shown in Table 2.

\section{3. $\mathrm{N}-\mathrm{NH}_{4}^{+} \quad$ Determination}

The amount of ammonium was determined by extracting $\mathrm{NH}_{4}^{+}$from soil with $0.5 \mathrm{M} \mathrm{K}_{2} \mathrm{SO}_{4}(1: 5 \mathrm{w} / \mathrm{v})$. The ammonium produced during the incubation period was then determined colorimetrically by a modified indophenol-blue reaction, based on the reaction of $\mathrm{Na}$ salicylate with $\mathrm{NH}_{3}$ and Na-dichlorisocyanurate. The intensity of the developed blue colour was measured at $690 \mathrm{~nm}$ [28].

\section{4. $\mathrm{N}-\mathrm{NO}_{3}^{-}$Determination}

$\mathrm{N}$ - $\mathrm{NO}_{3}^{-}$was extracted from soil with $\mathrm{K}_{2} \mathrm{SO}_{4}\left(10 \mathrm{~g}\right.$ sample and $50 \mathrm{ml}$ of $\left.0.5 \mathrm{M} \mathrm{K}_{2} \mathrm{SO}_{4}\right)$ and the $\mathrm{NO}_{3}^{-}$content in the extracts was recorded at $220 \mathrm{~nm}$. The true concentration of $\mathrm{N}-\mathrm{NO}_{3}^{-}$was obtained by subtracting the spectral interference at $275 \mathrm{~nm}$ due to the presence of organic matter from the results obtained at $220 \mathrm{~nm}$ [29].

\subsection{Soil Microbial Biomass Carbon (MBC)}

Soil microbial biomass carbon (MBC), which represents the quantity of $\mathrm{C}$ in the cells of living microorganisms in the soil, was determined according with the fumigation-extraction method [30]. Moist soil portions, each corresponding to $5 \mathrm{~g}$ of oven dried soil, were fumigated with ethanol-free chloroform for $24 \mathrm{~h}$, then extracted with $20 \mathrm{ml} 0.5 \mathrm{M} \mathrm{K}_{2} \mathrm{SO}_{4}$ for $30 \mathrm{~min}$. A set of non-fumigated soil samples was similarly extracted at the time fumigation commenced. The $\mathrm{K}_{2} \mathrm{SO}_{4}$ extractable organic carbon (OC) was determined by an OC analyser (Shimadzu TOC-VCSN). MBC was calculated from the equation $\mathrm{MBC}=\mathrm{K} \times \mathrm{EC}$, where $\mathrm{EC}=\left[\left(\mathrm{OC}\right.\right.$ extracted by $\mathrm{K}_{2} \mathrm{SO}_{4}$ from fumigated samples) (OC extracted by $\mathrm{K}_{2} \mathrm{SO}_{4}$ from non-fumigated samples)] and $\mathrm{K}$ (conversion factor) = 2.22 .

\subsection{Determination of Available Iron and Manganese}

Assessment of available Fe and Mn was conducted according to the DTPA/TEA method developed by Lindsay and Norwell [31]. Briefly, $20 \mathrm{ml}$ of DTPA/TEA were added to $10 \mathrm{~g}$ soil and the mixture was shaken for $2 \mathrm{~h}$. After centrifugation the supernatant was collected, filtered, stored at $20^{\circ} \mathrm{C}$ and subsequently analyzed by ICP-AES (Perkin Elmer, Optima 3000).

\section{Results and Discussion}

\subsection{Influence of ATS on Urease Activity in Untreated or in Urea Treated Soils}

There is general agreement that the soil urease strongly prevails in the hydrolytic process of urea and that the production of $\mathrm{NH}_{4}^{+}$can be a reliable expression for determining the enzymatic activity. As shown in Figure 1(a) and Figure 1(b), ATS significantly impaired urease activity in both soil types, but the exerted inhibitory effect was short-lived.

The maximum enzymatic inhibition occurred within the first three days when urease reached its lowest level in both the soils, and recovered afterwards with a different course. In comparison with the respective control, after application of 25 ppm S-ATS urease activity decreased by 23\% in the sandy-loam soil (A). However, the enzymatic activity recovered to the initial values within few days. In the sandy soil (B), application of the same dose of ATP resulted in a decrease in urease activity by $53 \%$. Conversely to soil A, the enzymatic activity did not recover afterwards, remaining at a lower level than that observed in the respective control soil. At the higher ATS dose (100 ppm S-ATS) the inhibition reached $43 \%$ in soil A and $82 \%$ in soil B, and persisted in both the soils until the end of the experiment. Our results therefore indicate that ATS had a more marked inhibitory effect in the sandy soil (B) which is characterized by a lower content of organic matter and higher $\mathrm{pH}$.

Concerning the treatments with urea, since samples were supplied with equal initial amounts of total $\mathrm{N}$ (i.e. $150 \mathrm{~kg} \mathrm{~N} \mathrm{ha}{ }^{-1}$ ) albeit $\mathrm{N}$ originated in different proportions from urea and ATS, the amount of extracted $\mathrm{NH}_{4}^{+}$ in amended soils resulted from hydrolysis of urea per se or urea plus ammonium from ATS. Therefore, in order to ascertain the net influence of ATS on the hydrolytic process of urea we normalized the data by subtracting $\mathrm{NH}_{4}^{+}$produced from ATS to the corresponding soil samples treated with urea. As evidenced by Figure 2(a) and Figure 2(b), the ammonium produced was ATS-dose and soil type dependent. 
(a)

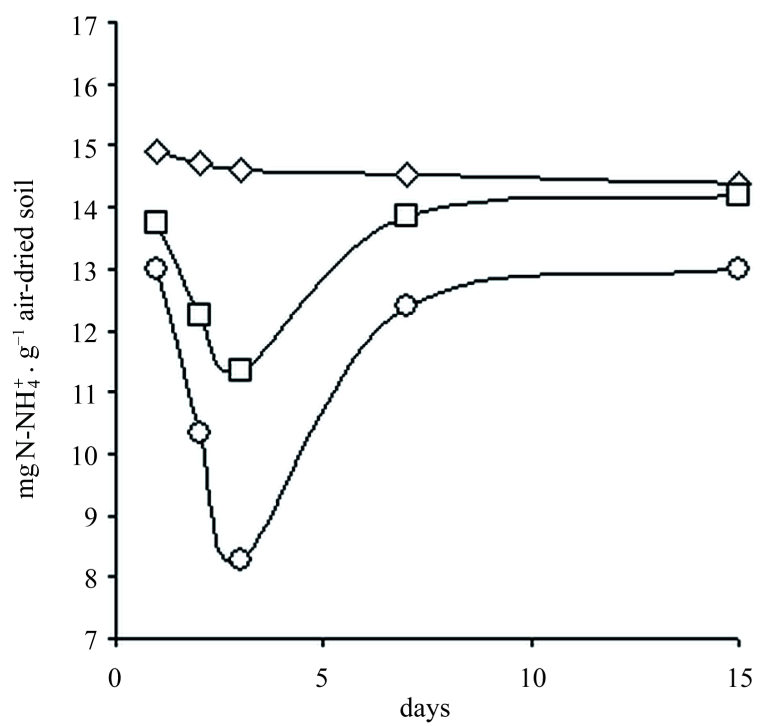

(b)

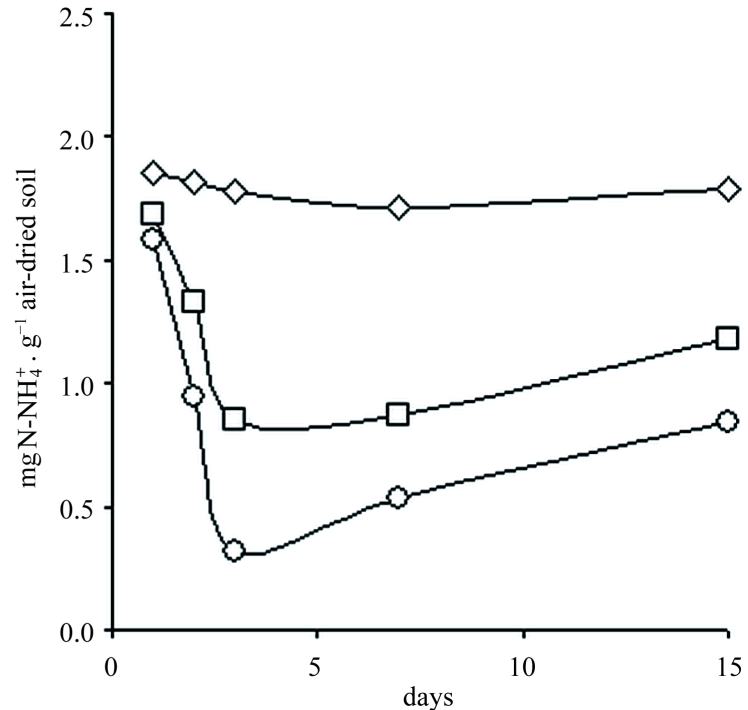

Figure 1. Dynamic of urease activity in sandy-loam soil (a) and in sandy soil (b). amended with 25 ppm ( $\square$ ) or 100 ppm (०) S-ATS, and no treated soil $(\diamond)$.

(a)

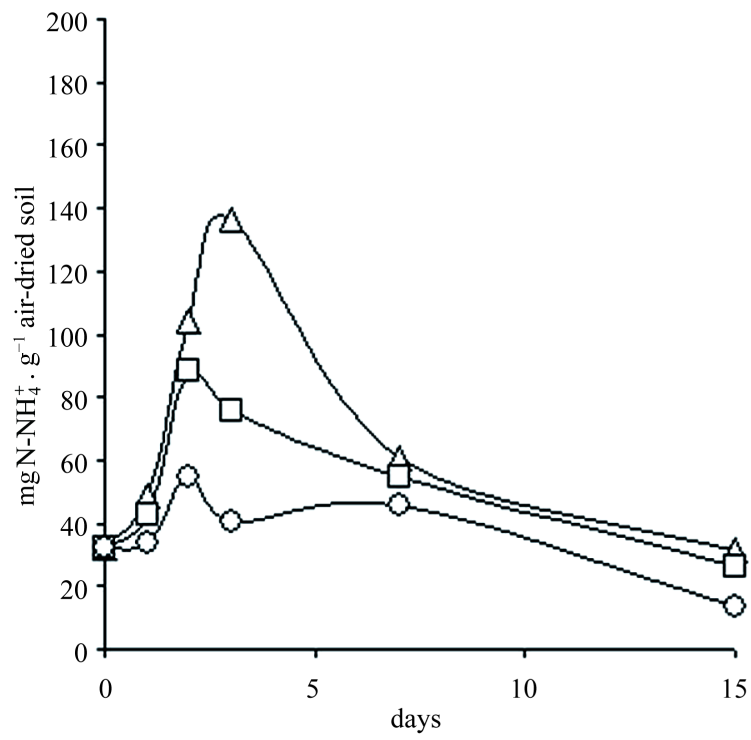

(b)

soil B

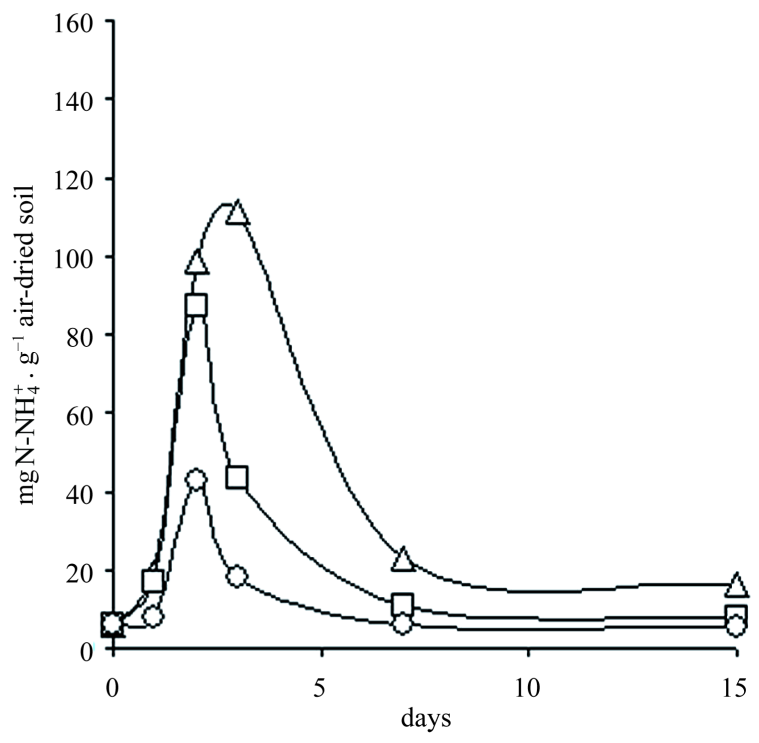

Figure 2. Dynamic of $\mathrm{N}^{-\mathrm{NH}_{4}^{+}}$concentration in samples of sandy-loam soil (a) and in sandy soil (b). Soils were treated with urea $(\Delta)$, urea +25 ppm S-ATS $(\square)$, and urea +100 ppm S-ATS $(\circ)$.

Application of urea alone significantly affected the ammonium production in both types of soil already after the first day, achieving the maximum level within 3 days of incubation, followed by a subsequent decline with different courses in soils A or B. In the sandy soil (B) characterised by a lower amount of organic carbon and a higher $\mathrm{pH}$, after reaching the maximum, $\mathrm{NH}_{4}^{+}$concentration sharply decreased to background values at the end of the first week. On the other hand, in the well textured sandy-loam soil (A) ammonium levels remained constant over time.

Comparing the levels of $\mathrm{NH}_{4}^{+}$in the treated soils, we observed that in sandy-loam soil (A) application of 25 ppm or 100 ppm S-ATS reduced the production of ammonium, and therefore urease activity, by $37 \%$ and $68 \%$, 
respectively. Even more evident was the inhibition of urease activity in the sandy soil (B) where the depression of $\mathrm{NH}_{4}^{+}$production reached $70 \%$ at the lower S-ATS rate and $88 \%$ at the higher.

The influence of soil properties on urease activity has been documented previously. For example, MacGarity and Myers [32] observed that urease was highly correlated with organic carbon, and Zantua et al. [33] reported evidence for the persistence of urease in soils high in organic matter. Concerning results obtained in our experiment, we suppose that the persistence of urease activity in ATS-treated soils could be a consequence of enzyme-protecting mechanisms exerted by soil components The adsorption of enzymes by minerals, humus and organo-mineral colloids is a common phenomenon in soil environment [34]. In particular, the functional groups occurring on the surfaces of soil inorganic and organic colloids show great affinity with extracellular urease, and formation of urease-colloidal complexes results in urease being stabilized and protected against hydrolytic process [35]-[38]. What is more, humic acids behave as supramolecules which are able to polymerize and aggregate, and form supramolecular ensembles with proteins, such as the enzymes [39] and hence retain the enzyme activity [40]-[45].

Moreover, specific chemisms which could have promoted the formation of water-soluble Shiff bases through reaction of ammonia produced from urea-hydrolysis with aldehydic/carbonyl functional groups of dissolved organic compounds can be co-responsible for the prolonged persistence of in the well-textured soil A. The formation of Shiff bases could have facilitated the persistence of ammonium into the soil solution thus reducing the risk of ammonia losses, and consequently increased potential efficiency of the $\mathrm{N}$-fertilizer.

Even though the specific mechanism through which ATS affects urease has still not been clearly assessed, the involvement of indirect pathways have been hypothesized. Thiosulphate is unstable when added to soils and is oxidized (via biological and chemical pathways), among other intermediate compounds, to the stable tetrathionate which is thought to be the actual urease inhibitor, by reacting with -SH groups in jack bean urease to give a S-sulpho derivative [46], as:

$$
\begin{aligned}
& \mathrm{RSH}+\mathrm{S}_{4} \mathrm{O}_{6}^{2-} \rightarrow \mathrm{RS}-\mathrm{S}_{2} \mathrm{O}_{3} \mathrm{H}+\mathrm{S}_{2} \mathrm{O}_{3}^{2-} \\
& \mathrm{RS}-\mathrm{S}_{2} \mathrm{O}_{3} \mathrm{H}+\mathrm{O}_{2} \rightarrow \mathrm{RS}-\mathrm{SO}_{3} \mathrm{H}+\mathrm{SO}_{2}
\end{aligned}
$$

There is general agreement that the formation of tetrathionate is largely abiotic, presumably mediated by transition metals, including Fe and Mn oxides as electron acceptors. Furthermore, Goos [18] and Sullivan and Havlin [24] assumed that reduced iron and manganese may also inhibit urease activity by altering the conformation of the sulphydryl groups in the catalytic center of the enzyme, according to the following simplified reactions:

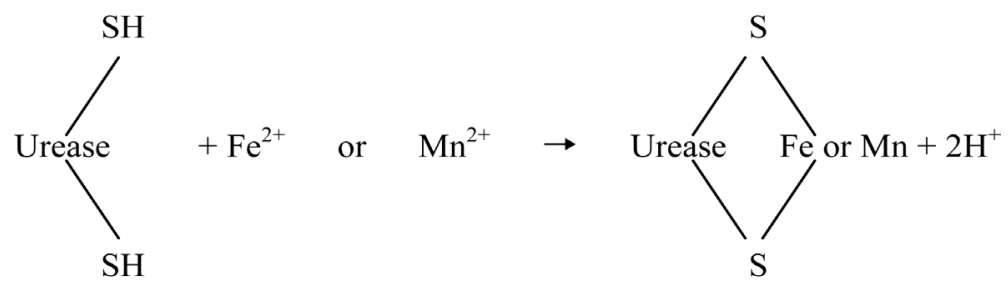

Being both a reducing and acidifying agent, thiosulphate has been recently proposed also as a tool for optimizing phytoremediation by enhancing the availability of inorganic contaminants in soil [47].

Since it was reasonable to suppose that even available fraction of Fe and Mn in examined soils would be improved by ATS addition we carried out a preliminary experiment to verify whether ATS would affect the mobility of Fe and $\mathrm{Mn}$ in soils during the incubation period, and to find a possible correlation between soil urease activity and the concentration of the available fraction of Fe or Mn.

Compared to the respective control soil, we observed that the available fraction of iron and manganese in both tested soils sharply increased after the application of ATS, reaching the highest amounts $(+11.7 \%$ and $+17 \%$ for Fe and Mn, respectively for soil B) within three days and decreased afterwards.

Due to the likely similar dynamics of urease activity (as $\mathrm{N}-\mathrm{NH}_{4}^{+}$production), we checked whether urease activity and available Fe and Mn were correlated, regardless of soil type and treatment in order to generalize a relation between the two parameters. By plotting the proportion of soil urease activity (Tn/T0) against available Fe and Mn (Figure 3) we observed a linear and significative correlation $\left(y=-4.7951 x+583.65, \mathrm{R}^{2}=0.9031\right)$ thereby providing evidence that the soluble fractions of iron and manganese indeed affect soil urease activity. 


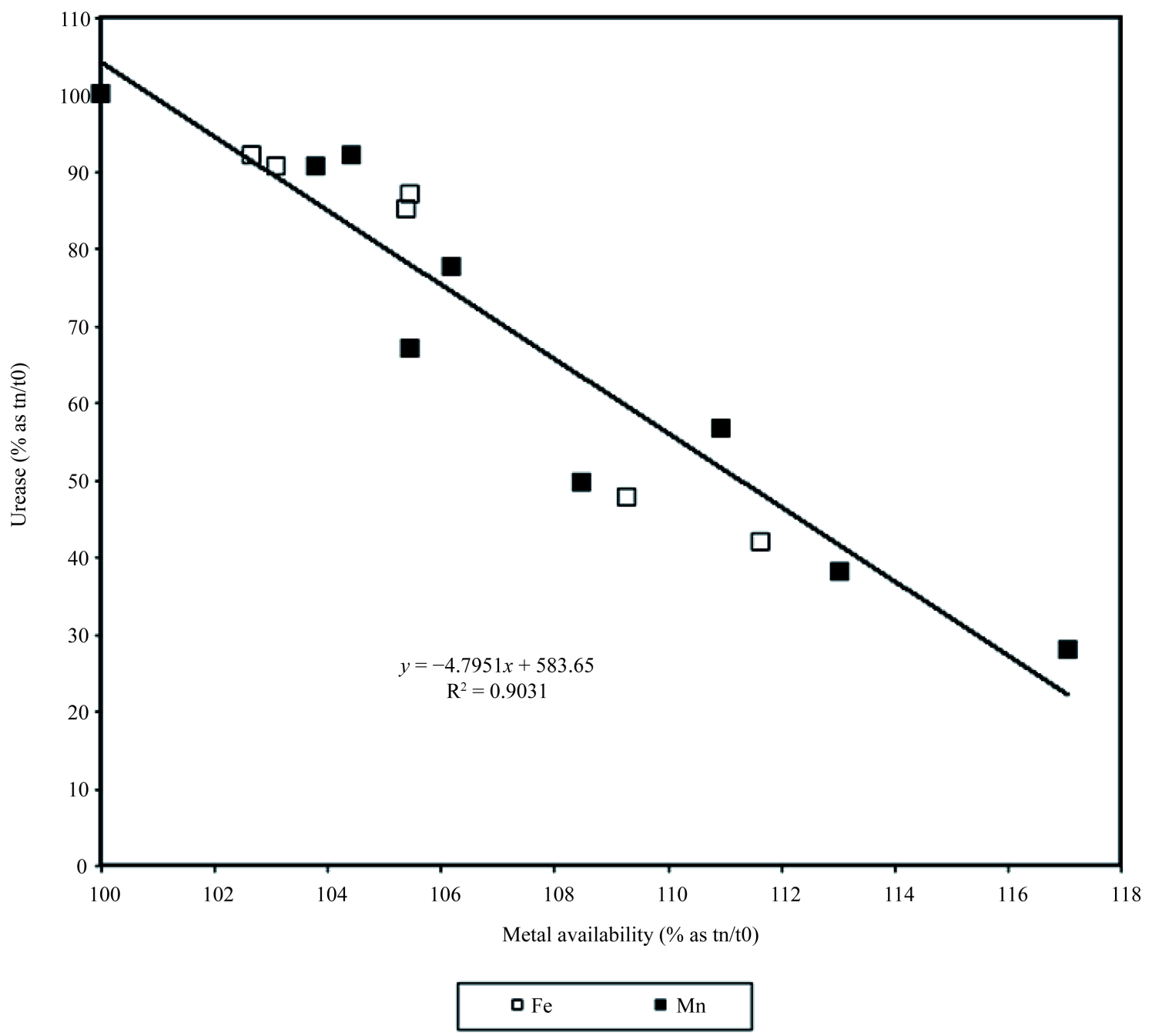

Figure 3. Relationship between soil urease and available Fe ( $\square$ ) and Mn (घ).

\subsection{Influence of ATS on Nitrification in Untreated or in Urea Treated Soils}

Even though ATS did not significantly affect the amount of nitrate extracted from both of the soils, we observed that ATS exerted an evident and significant inhibitory effect on nitrification in urea treated soils. Figure 4(a) and Figure 4(b) show the dynamics of the normalized amounts of nitrate (expressed as $\mathrm{N}-\mathrm{NO}_{3}^{-}$) in soils treated with urea (T1) or urea plus ATS (i.e. T4, T5).

Generally, when no ATS was applied (T1) nitrate rapidly increased throughout the two weeks of incubation, whereas the presence of thiosulphate delayed the initial nitrification rate and significantly reduced $\mathrm{NO}_{3}^{-}$formation. Evidence for the ability of ATS to delay nitrate formation has been reported in previous studies. Bremner [48] reported that the addition of ATS significantly retarded ammonium oxidation only at application greater than $500 \mathrm{ppm}$. Our results, however, showed evidence that ATS delayed $\mathrm{NO}_{3}^{-}$formation even when applied at considerably lower rates (25 ppm S-ATS).

Similarly to the results obtained for soil urease, the inhibition of nitrate production was more evident in the sandy-loamy soil (B), confirming the influence of soil properties on enzymatic processes, and nitrification in particular [49].

Several abiotic and biotic processes are considered to be involved in inhibition of nitrification by ATS. Janzen and Bettany [50] stated that the inhibitory effect of thiosulphste on nitrification may be largely attributable to a direct toxic effect of thiosulphate or its oxidation products (tetrathionate, carbon disulphide) on Nitrobacter sp. and other $\mathrm{NO}_{2}^{-}$oxidizing microorganisms. 
(a)

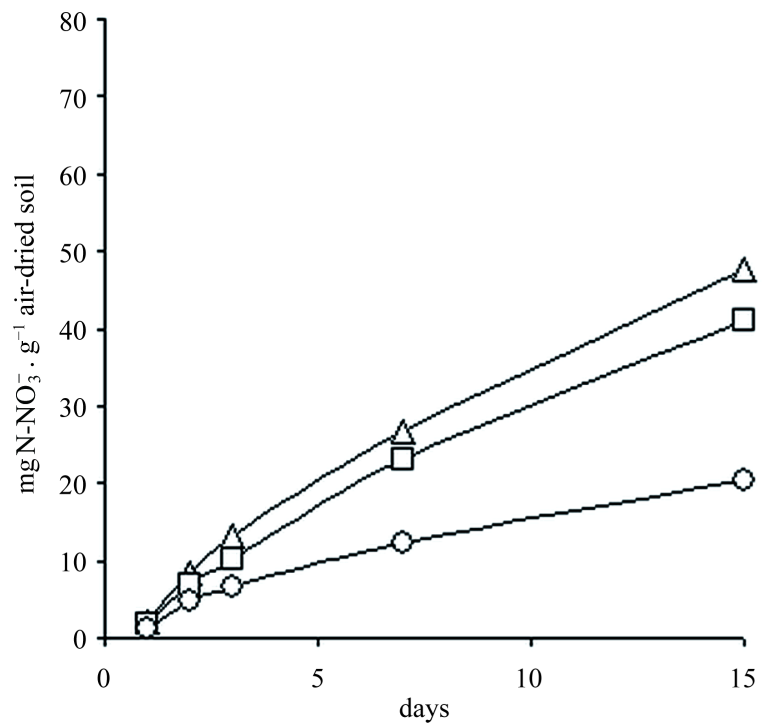

(b)

soil B

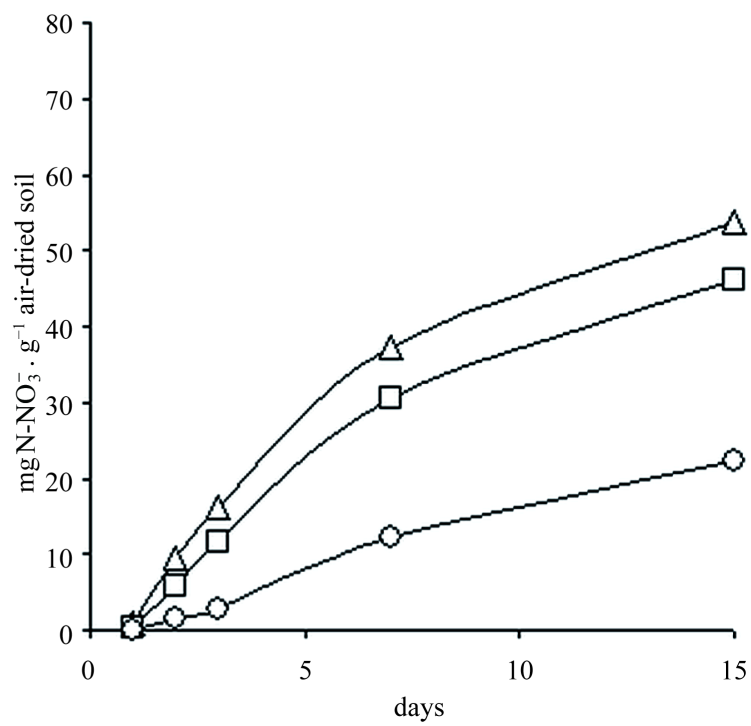

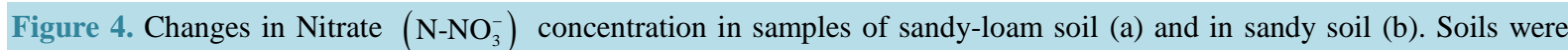
treated with urea $(\Delta)$, urea +25 ppm S-ATS $(\square)$, and urea +100 ppm S-ATS (०).

In our experiment, we noticed that the rate of $\mathrm{NH}_{4}^{+}$disappearance did not correspond to the rate of $\mathrm{NO}_{3}^{-}$ formation, suggesting that ATS led to the stabilization of $\mathrm{N}^{-} \mathrm{NH}_{4}^{+}$, and thus delaying the production of nitrate [51] [52]. In addition, our results are in accordance with those reported by Al Kanani et al. [53] who attributed the non-concomitant $\mathrm{NH}_{4}^{+}$to $\mathrm{NO}_{3}^{-}$conversion to the accumulation of nitrite, adversely affecting the amount and the activity of soil microorganisms, thus retarding nitrification

\subsection{Influence of ATS on the Size of the Soil Microbial Biomass in Untreated or in Urea Treated Soils}

It is generally assumed that soil microorganisms are the main agents of urea hydrolysis [54], and as we found that ATS inhibit soil urease activity, especially in sandy soil B, changes in the size of soil microbial biomass would be expected. The maintenance of soil fertility depends also on the size and activity of the soil microbial biomass, a small fraction of soil organic matter (1\% - 4\%). In addition, microbes, having both mass and activity and being in intimate contact with the soil microenvironment are, in many ways, ideal monitors of soil quality or perturbation [55] [56]. The evaluation of the size of soil microbial biomass, expressed as soil microbial biomass carbon (MBC), gives useful information about the deviation of the soil environment from its equilibrium. In our experiment, we found that the original size of soil microbial biomass did not change significantly in none of the ATS-amended soils. In effect, the amount of MBC ranged from 150 to $160 \mu \mathrm{g} \cdot \mathrm{g}^{-1}$ soil in sandy soil (B) and from 710 to $735 \mu \mathrm{g} \cdot \mathrm{g}^{-1}$ soil in sandy-loam soil (A), thus revealing that all the ATS-treatments had no effect on the total amount of original microbial pool.

\section{Conclusion}

The use of moderate inhibitors able to enhance the $\mathrm{N}$ availability in soils to meet the $\mathrm{N}$ demand of crops during a specific plants' physiological stage is consistent with the aims of precision fertilization. Results obtained in our experiment provide evidence that ATS alone or combined with urea exerted moderate inhibitory effects, both on soil urease activity and nitrification. In addition, we found that the inhibition was more evident when ATS applied to a sandy soil than to a sandy-loam soil, even at a low rate (25 ppm S-ATS). These characteristics are valuable in the context of optimizing the efficiency of $\mathrm{N}$ fertilization and also reducing nitrate leaching and ammonia volatilization in the early stages of crop growth when root growth and the plants' $\mathrm{N}$ uptake ability after the application of urea are limited. In addition, we observed that the microbial biomass size did not change sig- 
nificantly throughout the experiment neither of the investigated soils, revealing that ATS application had no negative effect on the native microbial pool, thus preserving the biotic component of soils. Our results also provide evidence that ATS application can be considered as an environmentally friendly tool among agronomic practices as it can be used both as liquid fertilizer for $\mathrm{N}$ and $\mathrm{S}$ plant nutrition and as a weak inhibitor of urease and nitrification. For all these characteristics we assume that farmers may use this product for many purposes and in different environmental conditions and in different farming systems. Because of its properties ATS could be applicable on many crops such as maize, wheat, rye, rape, etc., and in general on crops of high $\mathrm{N}$ demands and with a short growing period without being harmful on the soil microbial pool.

\section{Acknowledgements}

The authors greatly appreciated the technical assistance by Dr. Tjaša Jug of Agriculture and Forest Chamber of Slovenia, Agriculture and Forest Institute of Nova Gorica.

\section{References}

[1] European Commission (2012) Innovating for Sustainable Growth. A Bioeconomy for Europe. European Commission, Brussels.

[2] Tilman, D., Cassman, K.G., Matson, P.A., Naylor, R. and Polasky, S. (2002) Agricultural Sustainability and Intensive Production Practices. Nature, 418, 671-677. http://dx.doi.org/10.1038/nature01014

[3] FAO Statistical Yearbook 2013. www.fao.org/docrep/018/i3107e/i3107e00.htm

[4] Godfray, H.C., Beddington, J.R., Crute, I.R., Haddad, L., Lawrence, D., Muir, J.F., Pretty, J., Robinson, S., Thomas, S.M. and Toulmin, C. (2010) Food Security: The Challenge of Feeding 9 Billion People. Science, 327, 812-818. http://dx.doi.org/10.1126/science.1185383

[5] Baulcombe, D., Crute, I., Davies, B., Dunwell, J., Gale, M., Jones, J., Pretty, J., Sutherland, W. and Toulmin, C. (2009) Reaping the Benefits: Science and the Sustainable Intensification of Global Agriculture. The Royal Society, London. http://royalsociety.org/document.asp?tip=0\&id=8825

[6] Hall, S.J., Matson, P.A. and Roth, P. (1996) $\mathrm{NO}_{\mathrm{x}}$ Emissions from Soil: Implications for Air Quality Modeling in Agricultural Regions. Annual Review of Energy and the Environment, 21, 311-346. http://dx.doi.org/10.1146/annurev.energy.21.1.311

[7] Delmass, R., Serca, D. and Jambert, C. (1997) Global Inventory of $\mathrm{NO}_{\mathrm{x}}$ Sources. Nutrient Cycling in Agroecosystems, 48, 51-60. http://dx.doi.org/10.1023/A:1009793806086

[8] Shejbalová, Š., Černý, J., Vašák, F., Kulhánek, M. and Balík, J. (2014) Nitrogen Efficiency of Spring Barley in LongTerm Experiment. Plant, Soil and Environment, 60, 291-296.

[9] Tilman, D., Balzer, C., Hill, J. and Befort, B.L. (2011) Global Food Demand and the Sustainable Intensification of Agriculture. Proceedings of the National Academy of Sciences of the United States of America, 108, 20260-20264. http://dx.doi.org/10.1073/pnas.1116437108

[10] Heffer, P. and Prud'homme, M. (2011) Fertilizer Outlook 2011-2015. 79th IFA Annual Conference, Montreal, 23-25 May 2011, 1-9.

[11] Soares, J.R., Cantarella, H. and de Campos Menegale, M.L. (2012) Ammonia Volatilization Losses from Surface-Applied Urea with Urease and Nitrification Inhibitors. Soil Biology and Biochemistry, 52, 82-89. http://dx.doi.org/10.1016/j.soilbio.2012.04.019

[12] Doering, O.C., Galloway, J.N., Theis, T.L., Aneja, V., Boyer, E., Cassman, K.G., Cowling, E.B., Dickerson, R.R., Herz, W., Hey, D.L., Kohn, R., Lighy, J.S., Mitsch, W., Moomaw, W., Mosier, A., Paerl, H., Shaw, B. and Stacey, P. (2011) Reactive Nitrogen in the United States: An Analysis of Inputs, Flows, Consequences, and Management Options. EPA-SAB-11-013, Washington DC.

[13] Sutton, M.A., Erisman, J.W., Dentener, F. and Moller, D. (2008) Ammonia in the Environment: From Ancient Times to the Present. Environmental Pollution, 156, 583-604. http://dx.doi.org/10.1016/j.envpol.2008.03.013

[14] Meijide, A., Garcia-Torres, L., Arce, A. and Vallejo, A. (2009) Nitrogen Oxide Emissions Affected by Organic Fertilization in a Non Irrigated Mediterranean Barley Field. Agriculture, Ecosystems \& Environment, 132, 106-115. http://dx.doi.org/10.1016/j.agee.2009.03.005

[15] Sanz-Cobena, A., Sancez-Martin, L., Garcia-Torres, L. and Vallejo, A. (2012) Gaseous Emissions of $\mathrm{N}_{2} \mathrm{O}$ and NO and $\mathrm{NO}_{3}{ }^{-}$Leaching from Urea Applied with Urease and Nitrification Inhibitors to Maize (Zea mays) Crop. Agriculture, Ecosystems \& Environment, 149, 64-73. http://dx.doi.org/10.1016/j.agee.2011.12.016

[16] Dawar, K., Zaman, M., Rowarth, J.S., Blennerhassett, J. and Tutnbull, M.H. (2011) Urease Inhibitor Reduces N Losses 
and Improves Plant-Bioavailability of Urea Applied in Fine Particle and Granular Forms under Fields Conditions. Agriculture, Ecosystems \& Environment, 144, 41-50. http://dx.doi.org/10.1016/j.agee.2011.08.007

[17] Mueller, N.D., Gerber, J.S., Johnston, M., Ray, D.K., Ramankutty, N. and Foley, J.A. (2012) Closing Yield Gaps through Nutrient and Water Management. Nature, 490, 254-257. http://dx.doi.org/10.1038/nature11420

[18] Goos, R.J. (1985) Identification of Ammonium Thiosulphate as a Nitrification and Urease Inhibitor. Soil Science Society of America Journal, 49, 232-235. http://dx.doi.org/10.2136/sssaj1985.03615995004900010047x

[19] Fairlie, T.E. and Goos, R.J. (1986) Urea Hydrolysis and Ammonia Volatilization Characteristics of Liquid Fertilizer mixtures. Journal of Fertilizer Issues, 3, 86-90.

[20] Goos, R.J. and Fairlie, T.E. (1987) Effect of Liquid Fertilizer Composition and Droplet Size Urea Hydrolysis by Two Soils. Soil Science Society of America Journal, 52, 522-524. http://dx.doi.org/10.2136/sssaj1988.03615995005200020040x

[21] Murphy, M.D. (1998) Ammonium Thiosulphate as an Environmentally Friendly Tool for Reducing Inputs. End of Project Report ARMIS 4270, Johnstown Castle Research Centre, Wexford.

[22] Graziano, P.L. and Parente, G. (1996) Response of Irrigated Maize to Urea-Ammonium Nitrate and Ammonium Thiosulphate Solutions on a Sulphur Deficient Soil. Nutrient Cycling in Agroecosystems, 46, 91-95. http://dx.doi.org/10.1007/BF00704308

[23] Sullivan, D.M. and Havlin, J.L. (1988) Agronomic Use of Ammonium Thiosulfate to Improve Nitrogen Fertilizer Efficiency. Journal of Fertilizer Issues, 5, 37-44.

[24] Sullivan, D.M. and Havlin, J.L. (1992) Soil and Environmental Effects on Urease Inhibition by Ammonium Thiosulfate. Soil Science Society of America Journal, 56, 950-956. http://dx.doi.org/10.2136/sssaj1992.03615995005600030044x

[25] McCarty, G.W., Bremner, J.M. and Krogmeier, M.J. (1990) Evaluation of Ammonium Thiosulfate as a Soil Urease Inhibitor. Fertilizer Research, 24, 135-139. http://dx.doi.org/10.1007/BF01073581

[26] Sparks, D.L., Ed. (1996) Methods of Soil Analysis. Part 3. Chemical Methods. SSSA Book Series 5, Soil Science Society of America, Madison.

[27] Jenkinson, D.S. (1988) The Determination of Microbial Biomass Carbon and Nitrogen in Soil. In: Wilson, J.R., Ed., Advances in Nitrogen Cycling in Agricultural Ecosystems, CAB International, Wallingford, 368-386.

[28] Harwood, J.E. and Kuhn, A.L. (1970) A Colorimetric Method for Ammonia in Natural Waters. Water Research, 4, 805-811. http://dx.doi.org/10.1016/0043-1354(70)90037-0

[29] US Environmental Protection Agency (1983) Methods for Chemical Analysis of Water and Wastes, Method 353.3. USEPA Report No. EPA/600/4-79/020, Environmental Monitoring and Support Lab, Office of Research and Development, Washington DC.

[30] Vance, E.D., Brookes, P.C. and Jenkinson, D.S. (1987) An Extraction Method for Measuring Soil Microbial Biomass C. Soil Biology and Biochemistry, 19, 703-707. http://dx.doi.org/10.1016/0038-0717(87)90052-6

[31] Lindsay, W.L. and Norwell, W.A. (1978) Development of DTPA of Soil Test for Zn, Fe, Mn and Cu. Journal of American Soil Science, 42, 421-428. http://dx.doi.org/10.2136/sssaj1978.03615995004200030009x

[32] McGarity, J.W. and Myers, M.G. (1967) A Survey of Urease Activity in Soils of Northern South Wales. Plant and Soil, 27, 217-238. http://dx.doi.org/10.1007/BF01373391

[33] Zantua, M.I., Dumenil, L.C. and Bremner, J.M. (1977) Relationship between Soil Urease Activity and Other Soil Properties. Soil Science Society of America Journal, 41, 350-352. http://dx.doi.org/10.2136/sssaj1977.03615995004100020036x

[34] Nannipieri, P. (1996) Role of Stabilized Enzymes in Microbial Ecology and Enzyme Extraction from Soil with Potential Applications in Soil Proteomics. In: Nannipieri, P. and Smalla, K., Eds., Nucleic Acids and Proteins in Soil, Nucleic Acids and Proteins in Soil, Springer, Berlin, 75-94.

[35] Gianfreda, L., De Cristofaro, A., Rao, M.A. and Violante, A. (1995) Kinetic Behaviour of Synthetic Organo- and Organo-Mineral-Urease Complexes. Soil Science Society of America Journal, 59, 811-815. http://dx.doi.org/10.2136/sssaj1995.03615995005900030025x

[36] Gianfreda, L. and Rao, M.A. (2004) Potential of Extra Cellular Enzymes in Remediation of Polluted Soils: A Review. Enzyme and Microbial Technology, 35, 339-354. http://dx.doi.org/10.1016/j.enzmictec.2004.05.006

[37] Gianfreda, L. and Rao, M.A. (2008) Interaction between Xenobiotics and Microbial and Enzymatic Soil Activity. Critical Reviews in Environmental Science and Technology, 38, 269-310. http://dx.doi.org/10.1080/10643380701413526

[38] Nannipieri, P. and Gianfreda, L. (1998) Kinetics of Enzyme Reactions in Soil Environments. In: Huang, P.M., Senesi, N. and Buffle, J., Eds., Structure and Surface Reactions of Soil Particles, John Wiley \& Sons, New York, 449-479. 
[39] Pacheco, M.L., Peña-Méndez, E.M. and Havel, J. (2003) Supramolecular Interactions of Humic Acids with Organic and Inorganic Xenobiotics Studied by Capillary Electrophoresis. Chemosphere, 51 95-108. http://dx.doi.org/10.1016/S0045-6535(02)00846-9

[40] Guetzloff, T.F. and Rice, J.A. (1996) Micellar Nature of Humic Colloids. In: Gaffney, J.S., Marley, N.A. and Clark, S.B., Eds., Humic and Fulvic Acids, Isolation, Structure and Environmental Role, ACS Symposium Series 651, American Chemical Society, Washington DC, 18-25. http://dx.doi.org/10.1021/bk-1996-0651.ch002

[41] Mazzei, P. and Piccolo, A. (2013) Reduced Activity of $\beta$-Glucosidase Resulting from Host-Guest Interactions with Dissolved Fulvic Acids as Revealed by NMR Spectroscopy. European Journal of Soil Science, 64, 508-515. http://dx.doi.org/10.1111/ejss.12044

[42] Burns, R.G. (1982) Enzyme Activity in Soil-Location and a Possible Role in Microbial Ecology. Soil Biology and Biochemistry, 14, 423-427. http://dx.doi.org/10.1016/0038-0717(82)90099-2

[43] Burns, R.G. and Dick, R.P. (2002) Enzymes in the Environment: Activity, Ecology, and Applications. Marcel Dekker, New York. http://dx.doi.org/10.1201/9780203904039

[44] Marzadori, C., Francioso, O., Ciavatta, C. and Gessa, C. (2000) Activity and Stability of Jack Bean Urease in the Presence of Peat Humic Acids Obtained Using Different Extractants. Biology and Fertility of Soils, 32, 415-420. http://dx.doi.org/10.1007/s003740000272

[45] Nannipieri, P., Kandeler, E. and Ruggiero, P. (2002) Enzyme Activities and Microbiological and Biochemical Processes in Soil. In: Burns, R.G. and Dick, R.P., Eds., Activity, Ecology, and Applications, Marcel Dekker, New York, 1-36. http://dx.doi.org/10.1201/9780203904039.ch1

[46] Jocelyn, P.C. (1972) Chapter 16: Biochemistry of SH Group: The Occurrence, Chemical Properties, Metabolism and Biological Function of Thiols and Disulphides. Academic Press, New York.

[47] Petruzelli, G., Pedron, F., Tassi, E., Franchi, E., Bagatin, R., Agazzi, G., Barbafieri, M. and Rossellini, I. (2014) The Effect of Thiosulphate on Arsenic Bioavailability in a Multi Contaminated Soil. A Novel Contribution to Phytoextraction. Research Journal of Environmental and Earth Sciences, 6, 38-43.

[48] Bremner, J.M., McCarty, G.W. and Chai, H.S. (1986) Evaluation of Ammonium Thiosulfate as a Soil Nitrification and Urease Inhibitor. Agronomy Abstracts, ASA, Madison, 175.

[49] Sahrawat, K.L. (1983) Mineralization of Soil Organic Nitrogen under Waterlogged Conditions in Relation to Other Properties of Tropical Rice Soils. Australian Journal of Soil Research, 21, 133-138. http://dx.doi.org/10.1071/SR9830133

[50] Janzen, H. and Bettany, J.R. (1986) Influence of Thiosulfate on Nitrification of Ammonium in Soil. Soil Science Society of America Journal, 50, 803-806. http://dx.doi.org/10.2136/sssaj1986.03615995005000030047x

[51] Chaves, B., Opoku, A., De Neve, S., Boeckx, P., Van Cleemput, O. and Hofman, G. (2006) Influence of DCD and DMPP on Soil N Dynamics after Incorporation of Vegetable Crop Residues. Biology and Fertility of Soils, 43, 62-68. http://dx.doi.org/10.1007/s00374-005-0061-6

[52] Diez, J.A., Arauzo, M., Hernaiz, P.J., Sanz, A. and Vallejo, A. (2010) Comparison of Nitrification Inhibitors to Restrict Nitrate Leaching in a Maize Crop Irrigated under Mediterranean Conditions. Spanish Journal of Agricultural Research, 8, 481-492. http://dx.doi.org/10.5424/sjar/2010082-1212

[53] Al-Kanani, T., MacKenzie, A.F. and Blenkhorn, H. (1990) The Influence of Formula Modifications and Additives on Ammonia Loss from Surface-Applied Urea Ammonium Nitrate Solutions. Fertilizer Research, 22, 49-59. http://dx.doi.org/10.1007/BF01054807

[54] Klose, S. and Tabatabai, M.A. (1999) Urease Activity of Microbial Biomass in Soils. Soil Biology and Biochemistry, 31, 205-211. http://dx.doi.org/10.1016/S0038-0717(98)00090-X

[55] Brookes, P.C. (1995) The Use of Microbial Parameters in Monitoring Soil Pollution by Heavy Metals. Biology and Fertility of Soils, 19, 269-279. http://dx.doi.org/10.1007/BF00336094

[56] Leita, L., Muhlbachova, G., Mondini, C., Marchiol, L. and De Nobili, M. (1997) Soil Microbial Biomass as a Marker of Heavy Metal Contamination and Bioavailability. In: Rosen, D., Tel-Or, E., Hadar, Y. and Chen, Y., Eds., Modern Agriculture and the Environment, Kluwer Academic Publishers, Dordrecht, 449-457. http://dx.doi.org/10.1007/978-94-011-5418-5 37 